\title{
How Durkheim's Theory of Meaning-making Influenced Organizational Sociology
}

\section{Citation}

Dobbin, Frank. 2009. How Durkheim's Theory of Meaning-Making Influenced Organizational Sociology. In The Oxford Handbook of Sociology and Organization Studies, ed. Paul S. Adler, 200-222. Oxford, New York: Oxford University Press.

\section{Published Version}

10.1093/oxfordhb/9780199535231.003.0009

\section{Permanent link}

http://nrs.harvard.edu/urn-3:HUL.InstRepos:32970020

\section{Terms of Use}

This article was downloaded from Harvard University's DASH repository, and is made available under the terms and conditions applicable to Other Posted Material, as set forth at http:// nrs.harvard.edu/urn-3:HUL.InstRepos:dash.current.terms-of-use\#LAA

\section{Share Your Story}

The Harvard community has made this article openly available.

Please share how this access benefits you. Submit a story.

Accessibility 


\title{
THE OXFORD HANDBOOK OF
}

\section{SOCIOLOGY AND ORGANIZATION STUDIES}

\section{CLASSICAL FOUNDATIONS}

\author{
Edited by \\ PAUL S. ADLER
}




\section{HOW DURKHEIM'S THEORY OF MEANING-MAKING INFLUENCED ORGANIZATIONAL SOCIOLOGY}

\section{FRANK DOBBIN}

\subsection{INTRODUCTION}

EMILE Durkheim's Division of Labor has palpably influenced students of organizations, occupations, and stratification. Chapter 10, by Paul Hirsch, Peer Fiss, and Amanda Hoel-Green, documents Durkheim's influence by exploring his contribution to our understanding of the global division of labor. In this chapter I examine the influence of Durkheim's theory of meaning on organizational sociology, which has taken a cultural turn since the late 1970s with the rise of the new institutional theory (Meyer and Rowan 1977; DiMaggio and Powell 1983) and organizational culture theory (Barley and Kunda 1992; Schein 1996). As the founder of the cultural approach in sociology, Durkheim might well have won credit for the cultural turn in organizational analysis. But while he is frequently cited for his influence on 
symbolic interactionists, such as Erving Goffman (1974) and Karl Weick (1995), Durkheim is rarely cited by social constructionists who study organizations (but see Dobbin 2004).

Perhaps Durkheim has not often been credited with influencing cultural approaches to organizations because his ideas about culture have been absorbed and have been refracted through the influence of cultural anthropology on sociology (Lévi-Strauss 1978; Douglas 1966; Geertz 1983). Or perhaps it is because certain themes in Durkheirn's work were appropriated by Talcott Parsons, and Parsons's structural functionalism was the paradigm that culturalists fought against (Lincoln and Guillot 2005). In other words, Durkheim may have posthumously sided with the enemy of cultural theorists of organizations.

Yet Durkheim's ideas about the social underpinnings of cognition, and about our inclination to act collectively to make sense of the world by classifying things and attaching meaning to them, inform much of the cultural work in organizational sociology. In his early work on the division of labor and suicide, Durkheim tackled the issue of social attachment to the group from a structural and normative perspective by asking how societal cohesion cotild work in the context of occupational divisions (Division of Labor) or in religions with weak normative control systems (Suicide). His later anthropological work on tribes was also concerned with social attachment to the group, but there his focus was cultural rather than structural or normative. In The Elementary Forms of the Religious Life ([1912] 1961), Durkheim outlined a micro theory of behavior that was more collectivist than the theories that Marx or Weber had outlined and more focused on meaning-making (as opposed to self-interest) (Swedberg 2003; Lukes 1985). Durkheim emphasized that even the basic categories of meaning - time and space-could only be produced collectively and that the drive to make meaning is fundamental, in much the way that Karl Marx or Adam Smith saw self-interest as fundamental.

In Elementary Forms, Durkheim showed that tribes collectively make sense of the world through categorization. They categorize entities from the plant and animal worlds, making connections between human communities and totems, between individuals and their personal totems. Their explanations of how things are grouped together are mystified, rather than scientistic (our own explanations would begin with species and genus, for instance, and so a frog totem and spiritual leader would not be grouped together), and so the connections between things are understood in terms of a spirit system-the link between the totem and fertility, for instance. Their myths locate the origins of social practices outside of sociall life, in an external world of spirits. These 'elementary forms' of religious life are early drafts of modern religious systems and contain all of the elements of spirituality, ritual, sacred and profane. Thus, the meaning-making found in totemic systems, which involves categorizing animate and inanimate things in the surrounding world as well as social conventions, underlies modern religious systems as well. 
Social constructionists have built on these insights to argue that the rationalization of the modern world parallels the mystification of the pre-modern world. Human groups identify an external source of social customs, whether that source be transcendental spirits, under animism, or transcendental economic laws, under contemporary norms of scientific rationality. In organizational theory, social constructionists depict the evolution of modern laws of efficiency and rationality as a process paralleling that which Durkheim described in totemic societies. Meyer and Rowan (1977) famously describe organizational practices as myth and ceremony, taking a page from Durkheim's work on totemic societies to characterize rationalized meaning systems. Durkheim himself had seen this connection between different sorts of worldviews, not only in describing totemism as an 'elementary form of religious life' in the title of his 1912 book but also in describing modern economic theory as akin to metaphysics, in that it establishes an extra-societal force (economic laws) that drives worldly behavior.

In this chapter, I sketch Durkheim's contribution in Elementary Forms and, in particular, his idea that humans are driven to understand the world through collective classification and meaning-making. Then I show how that idea informed postwar sociologists of knowledge and organizational sociologists: Erving Goffman, Peter Berger and Thomas Luckmann, and James March and Herbert Simon. Finally, I describe Durkheim's influence on organizational sociology since the late 1970s, particularly on the new institutionalism and second-generation power theory. To begin with, I discuss how his work on meaning evolved from his early work on social structure.

\subsection{DURKHEIM'S EARLY WORK on Social Structure}

Emile Durkheim was born in 1858 in the province of Lorraine to a family of three generations of rabbis. His dissertation, The Division of Labor in Society ([1893] 1933), and books on the sociological method ([1895] 1966) and suicide ([1897] 1966), provided a new model for the study of society, a model that was scientific rather than humanistic, with a focus on social structure and social solidarity. In Division of Labor, Durkheim asked how social solidarity was maintained in agricultural and industrialized societies, and he showed that different social structures corresponded to different forms of solidarity. Under feudalism, solidarity emerged from the fact that people shared a common situation in the social structure and common life experiences. Mechanical solidarity in agricuitural systems was a result of shared experience. But with industrialization, the division of labor undermined common 
life experience as a form of solidarity. Now people had very different life experiences depending on their places in the occupational structure. Industriatization had challenged the classical form of social solidarity. What emerged in its place was organic solidarity, in which solidarity was a function of each person's dependence on others in the social system. The butcher depended on the baker, the mason on the lumberjack. Within occupations and professions, however, bonds of solidarity still emerged based on shared experiences and circumstances.

In Suicide, Durkheim built on this understanding of social attachment to the grotsp to analyze suicide rates across different societies and regions, finding that suicide rates rise in settings where people become anomic, or detached from the group. In Protestant regions people are more detached than in Catholic regions because the Protestant denominations exert less social control than the Catholic Church. Normative social control, then, is a key mechanism attaching the individual to the social group. But there is an ideal level of normative control, and suicide rates rise again in settings with too much social integration, where social control becomes oppressive. Suicide not only treated the issue of group attachment from a social control perspective but also showcased the scientific approach Durkheim had set out in Rules of Sociological Method, where he argued that, to establish causality, social scientists must compare societies, or groups, to establish causal patterns. He compared statistics from different countries, and from different regions within countries, to garner evidence that suicide rates indeed vary with social integration. Following his precepts in Rules of Sociological Method, he amassed evidence from diverse sources to show the generality of the relationship between anomie and suicide. In Rules of Sociological Method, Durkheim had sketched a general method for studying social phenomena, emphasizing the need to treat social facts as phenomena worthy of scientific study, and the importance of making comparisons across individuals and groups to accumulate evidence for a theory.

Elementary Forms represented a break in Durkheim's oeuvre, in a sense, in that he turned from modern societies to pre-modern tribes and moved from Europe to Australia, China, and the Sioux. But it represented continuity on two important fronts. First, Durkheim continued to be interested in social solidarity and cohesion, and in Elementary Forms he sought to understand the religious and cultural forces that produce cohesion and collective consciousness. He was fascinated by the 'collective effervescence' in religious rituals that made tribal members, and modern worshippers, believe in a force beyond society. The turn to tribal societies was deliberate, for Durkheim sought to trace the modern religious forces that produce social cohesion to their originals in tribal spirituality. In Elementary Forms, moreover, Durkheim continued to insist on the importance of social facts. At the time, some economists had been arguing that all social phenomena could be traced to the individual (pursuing methodological individualism), and it was in that context that Durkheim insisted that social facts themselves shape subsequent social phenomena. In the tribes he studied, the tribe's belief system was a social fact that palpably 
shaped future beliefs and behaviors. For Stephen Lukes (1985), Durkheim at times reified society in this work, in the process of arguing that tribal members deified their own society in inventing a spirit world that reflected it.

The second way in which Elementary Forms represented continuity with Durkheim's earlier work is that it applied the methodological dictates from Rules of Sociological Method. Rather than focusing on a single tribe, which had been the modus operandi in anthropology, Durkheim conducted a systematic comparison of ethnographic materials from tribes in Austratia, China, and North America to understand the most fundamental patterns of meaning-making. He drew lessons from the patterns these tribes shared, not from their idiosyncrasies.

\subsection{DURKHEIM'S THEORY OF MEANING}

The view of culture that emerges in Elementary Forms can be seen in Durkheim's earliest work. He saw culture as a product of social processes, but as a consequential product that influences social phenomena. In Suicide, he wrote that once cultural representations are in place, 'they are, by that very fact, realities sui generis, autonomous and capable of producing new phenomena' (Durkheim [1897] 1966: 130). Or as Lincoln and Guillot (2005:97) describe Durkheim's view of culture: 'Culture may originate with social structure, but people experience structure through cultural frames and filters.' Cultural meanings are social facts just as social structures are social facts, facts which sociologists should endeavor to explain and should use in explaining other social phenomena.

Durkheim's ideas about cognition and categorization were first set out in 1902, a decade before Elementary Forms appeared, in an essay titled 'Primitive Classification' (Durkheim and Mauss [1902] 1963), which appeared as 'De Quelques Formes de Primitives de Classification' in Année Sociologique. 'Primitive Classifcation', which Durkheim wrote in collaboration with his nephew Marcel Mauss, set out ideas that would be developed by structural anthropologists in France. Evidence from Australian tribes, the Zuni and Sioux, and China provided the empirical foundation for the argument that classification systems originate in social organization-that symbolic systems derive from the organization of social life.

In Elementary Forms, which appeared in French in 1912 and in English translation in 1915, Durkheim built on that collaborative effort to understand the emergence of tribal sacred systems. Whereas others before him bad seen these belief systems as arising from a need to understand the mysteries of the real or dream worlds-from psychological phenomena--Durkheim saw sacred totemic systems as originating in the need to understand the power of the social group over the individual. Here, as in Division of Labor and Suicide, he is fascinated by individual attachment to 
the group. He identifies a sort of cognitive dissonance in Australian tribes, whose members wonder how particular people and groups can exert such influence over them. They explain this power with reference to a sacred world beyond direct observation. The totem represents what is transcendental in social life. This insight represents a major break with anthropologists of the time, and in a sense it underlies the social constructionist theory of cognition that informs cultural approaches in organizational theory.

For Durkheim, the human mind is programmed not to maximize self-interest so much as to develop categories, causal frameworks, and maps of the world as a means of sense-making. We do this collectively. Australian tribes categorized the world in ways alien to Durkheim, lumping the tribe with the totem, animals with plants, and so on. Their categories were based on affinities tribe members believed had been established by the spirit world, which gave power to certain objects and social roles. Sacred objects (an animal or plant totem) give meaning to the social group and confer sacred powers, often through direct physical contact. Thus, the totem is inscribed on arrows to bring its powers to the hunt. In Durkheim's view, the spiritual world is an abstraction and reflection of the social world, which, being a social fact, acts back upon the social world.

The world is given intersubjective meaning through social processes, where categories, maps, frames, and causal models become part of a collective language. Social categorization confers the status of sacred or profane on everything the tribe experiences. Tribes locate socially produced conventions and meanings not merely outside of the individual, but outside of the social world itself in a system of spirits.

By comparing the religious systems of different tribes, Durkheim saw that individual consciousness comes to reflect social conventions and the collective consciousness (shared understanding) that develops to make sense of conventions. Conventions themselves take many different forms, largely as a result of happenstance. Tribes elevate the lizard or frog or anteater as their totem as a result of historical accident, without any larger rhyme or reason. Durkheim insisted at the end of Elementary Forms that modern religious systems were built on the same foundations as totemic systems, meaning, on the one hand, that they were likewise organized around spirituality, ritual, the sacred and profane, and, on the other hand, that their particular forms were consequences of history and happenstance.

Durkheim challenged classical economists' view of the individual as driven by narrow self-interest. He also challenged economists' methodological individualism, or the idea that social patterns must be based in human nature. The commitment to self-interest and methodological individualism was at the base not only of neoclassical economics but also of the political philosophy of Thomas Hobbes (1982) and John Locke (1965), who depicted modern social and economic institutions as built up from the interactions of individuals pursuing their interests. The consequence of free individual exchange was the spot market, and market and political institutions followed from this free exchange. Because pursuit of selfinterest is natural, the theory goes, social and economic institutions that allow 
free exchange are merely a reflection of the human soul (Somers 2001). Durkheim challenged this view in describing collective consciousness as emerging from the interaction of group members rather than from the qualities of the individual. While he described society as the individual mind writ large, which might be read as compatible with the view of classical economics, Mary Douglas (1986: 45) argues that Durkheim was pointing out the correspondence between mind and society, and that it is more in the spirit of his work "to think of the individual mind furnished as society writ small'.

Like Durkheim, Marx and Weber saw the human psyche as shaped quite fundamentally by social institutions; however, the process of collective meaning-making was much more fundamental to Durkheim than it was for either Marx or Weber. Like Durkheim, Marx and Weber saw the human psyche as shaped quite fundamentally by social institutions; however, the process of collective meaning-making was much more fundamental to Durkheim than it was for either Marx or Weber. Weber (1978:4) turned the observation that meaning varies from society to society into a methodological dictum, arguing that, to understand social action, one must understand its meaning to the actor. In The Eighteenth Brumaire, Marx ([1852] 1963: 1) famously wrote, 'Men make their own history, but they do not make it as they please; they do not make it under self-selected circumstances, but under circumstances existing already, given and transmitted from the past.' History leaves not only material relations but also a framework that shapes consciousness. Yet Marx saw class interests underlying frameworks of meaning and described those interests as key and frameworks as only 'superstructure'. For Marx ([1859] 1968: 181), forms of consciousness emerge to support the 'real foundation' of society, "the economic structure... on which arises a legal and political superstructure and to which correspond definite forms of consciousness'. While there is scholarly debate over whether Marx saw consciousness as merely epiphenomenal, as this passage implies, there is little debate that Durkheim gave it greater primacy of place in his work. For Marx, genuine material relations can be obscured by group consciousness and what mattered most were those material relations. For Durkheim, collective consciousness could not be wrong, for it was a gloss on experience, and could not be mereiy epiphenomenal, because collective consciousness is a social fact with concrete effects.

\subsection{Durkheim's Influence on Post-War Sociologists of KNOWLEDGE}

Durkheim's thinking shaped much of the work of post-war American social constructionists and symbolic interactionists. Erving Goffman (1974) drew on Durkheim's notion of how meaning is created in social groups, building on 
Burkheim's notion that the individual in the modern world 'is allotted a kind of sacredness that is displayed and confirmed by symbolic acts' and arguing that 'a version of Durkheim's social psychology can be effective in modern dress' (Goffman [1967] 2005: 47). Societies offer different 'frames' for understanding the world that are situated in individual consciousness, but that are shared among groups of people exposed to common institutions. In French organizational sociology, the convention school expanded on this idea to suggest that people are exposed to a multitude of different frames-market efficiency, democracy, economic justice-and depict action in terms of one such frame or another (Boltanski and Thevenot 1991). Randall Collins (2004) takes Durkheim's work on ritual as a starting point for expanding on Goffman's interactionism, building social institutions up from dyadic interactions.

While Peter Berger and Thomas Luckmann build explicitly on Alfred Schutz's The Phenomenology of the Social World ([1932] 1967) to sketch a social constructionist view of human cognition, their approach can be seen as an extension of Durkheim's project in Elementary Forms, for they seek to understand how social understandings of the world come about not only in tribal and religious systems, but in philosophical and scientific-rational systems. Berger and Luckmann (1966: 20) say that their task is to grasp 'the objectivations of subjective processes (and meanings) by which the intersubjective commonsense world is constructed. How is it, in other words, that our subjective 'knowledge' of the world comes to have the feel of an objective reality? The fact that those around us share that subjective knowledge heips to give it the feel of objective fact, and so we do not see the socially constructed reality around us as a social product.

For Berger and Luckmann, the inclination to assign objective status to intersubjective reality is characteristic of human society. In mystified, religious, philosophical, and rationalized social systems alike, individual's make causal connections on the basis of the wider system of meaning institutionalized in concrete customs. That was one of Durkheim's points about totemic and modern religious systems alike. Compare quotes juxtaposed by Finn Collin (1997:4) from Elementary Forms and The Social Construction of Reality. In the first, Durkheim makes clear (as he did in The Rules of Sociological Method ([1895] 1966) that ideas about reality are what we know of reality: 'There is one division of society where the formula of idealism is applicable almost to the letter: this is the social kingdom. Here more than anywhere else the idea is the reality' (Durkheim [1912] 1961: 228). In the second, Berger and Luckmann make the same point, and then underscore how people participate in sustaining ideas about reality: "Knowledge about society is thus a realization in the double sense of the word, in the sense of apprehending the objectivated reality, and in the sense of ongoingly producing this reality.... The sociology of knowledge understands human reality as socially constructed reality' (Berger and Luckmann 1966: 210-11).

For Berger and Luckmann, as for Durkheim, modern societies are not so different from tribal societies, in that they trace social conventions to something 
outside of society, in the modern case to natural laws (laws of the market, laws of 'human nature') that are unvarying across time and space. For them, human cognition is a reflection of the surrounding social order. We are rational actors, but only because we live in a universe governed by imagined scientific laws. In a universe governed by ancestors, our cognitive structures would reflect the imagined world of ancestors. Moreover, rationalized cognitive systems come in as many flavors as mystified cognitive systems because the laws of rationality are social inventions. Through objectivation, we come to see the social construction of the universe we know, mystiffed or rationalized or whatever, as natural and true rather than as a social product.

Berger and Luckmann used slightly different language to describe the process by which societies categorize objects to make sense of them (1967: 4), but as Bryan Turner (1997: 378) writes, their arguments owe homage both to Marx and to Durkheim: 'These Propositions can be seen as a summary of the theories of alienation and anomie, of Marx's claim in The Eighteenth Brumaire of Louis Bonaparte that "Men make their own history, but they do not make it just as they please" and of the theory of the conscience collective in Durkheim.'

This view of the modern psyche as, like the tribal psyche, a social product rather than a realization of human nature continues to fuel debate in the social sciences. Avner Greif (1993) has argued that rational self-interested behavior was found in the trading patterns of antiquity, with the corollary that self-interest and the inclination to truck and barter in modern form are hard-wired. Yet Albert Hirschman's The Passions and the Interests (1977) challenges that view, tracing the historical rise of interest as a framework for understanding human behavior. That framework replaced a view of human behavior as driven by such innate passions as greed and lust. Sociologists from Max Weber (1978) to Richard Swedberg (2003) have seen nascent elements of self-interest in early modern Europe, but Neil Smelser's (1995) review of anthropological evidence suggests that, in aboriginal societies, members did not view self-interest as underlying their own behavior and did not create incipient modern markets. It is more in keeping with Durkheim's view to see economic theory as a social fact than as an extra-social fact, and hence to explore how humans made up this theory as a way to explain the world of experience.

\subsection{DURKHEIM'S INFLUENCE ON Organizational Sociology}

Beyond Goffman's idea of frames, and Berger and Luckmann's work on the social construction of reality, many others in sociology have built on Durkheim's ideas about the correspondence between social structure and psyche, and on the social 
creation of the psyche. Pierre Bourdieu's habitus describes the class-based schemas for seeing the world that come from the social world. Ann Swidler (1986) uses 'cultural tool-kit' to describe the shared cultural elements that people use to interpret the world and act upon it. Luc Boltanski and Laurent Thevenot (1991) use the term 'justification' to refer to the menu of standard culturally constructed ways of understanding social action. Societies produce broadly different sorts of cognitive orientations - maps of reality-and modern societies create multiple, overlapping, maps.

In organizational sociology, March and Simon (1958) and organizational culture theorists describe the social construction of reality found within each organization (Schein 1996; see Pedersen and Dobbin 2006). At the other end of the micromacro continuum, cultural psychologists characterize broad national differences in those maps. Cross-national studies of the human psyche confirm that societies produce different models of social order. Experiments have shown that people in different countries describe the same picture in very different ways, Americans focusing on the subject and Japanese focusing on the context (Nisbett et al. 2001). Hence Americans are more likely to attribute the behavior of others to character, while Japanese are more likely to attribute it to context. Recent work in infant cognition seems to challenge some of Durkheim's basic assumptions by suggesting that certain categories of cognition are hard wired (see Bergesen 2004), but this comparative work in psychology shows consistent societal patterns suggesting that context shapes some quite fundamental categories (see DiMaggio 1997).

Next I trace Durkheim's influence on several lines of thought important to organizational sociology. James March and Herbert Simon's 'Cognitive Limits on Rationality' sketches how members of organizations develop rationalized routines for solving problems, and how they come to apply these routines as rationalized rituals to solve problems. The psychologist Karl Weick explores cognitive sensemaking within organizations, showing how people explain their own behavior post hoc, to themselves and to others, in socially meaningful terms. We invent meaningful rationales for action after we have acted, simultaneously reinforcing existing rationales and justifying our own behavior. New organizational institutionalists depict the interorganizational construction of rational myths and rituals, which spread through the network of organizations. Second-generation power theorists have built on the social constructionist insights that Durkheim first sketched to explain how we come to accept institutions that reinforce power differentials.

\section{5.x. Cognition in Organizational Tribes: Bounded Rationality}

James March and Herbert Simon's classic Organizations (1958) sketches how habits and routines reproduce themselves in today's organizational tribes. Within an organization, customary problem-solving strategies influence how people respond 
to new problems, following habits rather than engaging in fully rational search processes for optimal solutions. Organizational members use habitual solutions to solve new problems, identifying characteristics of the new problem that correspond with characteristics of an earlier problem, and applying the solution applied in that situation. Thus, what the organizational tribe has done in the past shapes how current members behave.

March and Simon focus on the limits of human cognitive capacity in rational decision making. Managers are seldom able to identify the optimal means to a particular end because of the difficulty of assessing the costs and benefits of each imaginable strategy. They act out of habit and adapt existing customs to new problems. They typically settle on solutions that meet minimal criteria for achieving a goal rather than searching for the ideal solution, 'satisficing' rather than optimizing. Rather than fully exploring all options, people begin the search process by thinking of an analogous problem from the past. They apply a solution similar to that applied in the analogous case, expanding beyond off-the-shelf remedies only when they can think of no analogous situation. What March and Simon describe is almost indistinguishable from what Durkheim describes in the tribe, where members inscribe the tribe's totem on every tool crafted for the hunt. In both cases they enact the tribe's customs without much thought about what they are doing.

Organizations, like tribes, offer different menus of past solutions to choose from. They develop precise problem-solving routines for dealing with common and predictable functions and general routines for dealing with rare and unpredictable functions. The routines exist as organizational culture at the level of the firm and as cognitive problem-solving scenarios in the minds of individuals. March and Simon argue that customs and cognitive frameworks are really two sides of the same coin, for cognitive frameworks reflect the customs individuals encounter in their work organizations. That is very much the modei of the social world that Durkheim described for totemic and modern religious systems alike.

March and Simon's idea of bounded rationality, in which the way we see the world is influenced by the social constructions in our environment, is certainly compatible with Durkheim's view of collective consciousness. In both models the collectivity develops an interpretive framework that shapes the behavior of members-their understandings are not their own, neither devised autonomously nor a consequence of the way the brain is wired ('human nature').

Simon's interest in routine can be traced to John Dewey. Durkheim as well had been influenced by Dewey and the pragmatists, and while he critiqued the approach, it was a proximate critique of intellectual differentiation not a distant critique of intellectual rejection (see Michael D. Cohen, 'Reading Dewey: Some Implications for the Study of Routine', in this volume). In his 'transactional' pragmatism, Dewey treated knowledge as a socially produced system, expressed in language, that was constantly open to amendment and reinterpretation. Durkheim's own view of knowledge, produced in society as collective consciousness, was 
guite similar, and his belief in using the scientific method to refine knowledge about society in particular overlaps with Dewey's view (Joas 1993; Dewey 1998). Dewey was, not surprisingly then, Durkheim's favorite philosopher (Martin 2002).

Cultural sociologists have shown that conventions vary across nations, but March and Simon point to how they vary in important ways even across work organizations in the same nation and industry, shaping workers' cognitive frameworks and problem-solving toolkits. For March and Simon, people in modern work organizations pursue rationalized solutions to problems, but those solutions are determined by organizational culture. Rationality, then, takes different cultural forms in different organizations just as totemism, for Durkheim, takes different forms in different tribes. Sociologists have expanded on this observation to show that across countries, the repertoire of rationalized management practices varies widely (e.g., Hofstede 1980; Whitley 1992). 'National character' used to be thought to explain these differences, and character was thought to be passed down from parents to children. But scholars have increasingly treated national differences as consequences of the social construction of national institutions (e.g., Whitley and Kristensen 1996). Thus, the institution of lifetime employment for managers in Japan (Dore 2000) or getting ahead by moving around in the United States shapes collective consciousness. It is not that one system is rational and the other prerational, but that different rationalized rituals, and worldviews, emerge in different settings.

\subsubsection{Seeing Action through the Tribe's Kaleidoscope}

In exploring the relationship between social structure and individual cognition, Durkheim's followers argue that human customs are framed as driven by forces outside of society. The rationalized organizational customs March and Simon describe are tied to universal principles of rationality (formalism, bureaucracy, professionalization). The sense-making approach to organizations builds on these ideas, returning the focus to the individual and his or her interaction with the existing meaning system. In Sensemaking in Organizations (1995), Karl Weick examines how frames for understanding the world are activated and manipulated by individuals. Weick does not see the meaning of an action as tightly wedded to the action itself, but instead sees individuals as operating with a range of interpretive frames. People make sense of much of their behavior retrospectively, using these interpretive frames. Weick illustrates with Garfinkel's study of jury decisions, which shows that jury members tend to select a punishment first, and then make sense of the evidence so that the crime fits the punishment. For Weick, organizational behavior tends to follow the same pattern. People act first, and later develop rationales for that action based in existing, socially accepted, frameworks. 
Weick's innovation is the idea that action shapes cognition-that we make cognitive sense of even our own actions after they have occurred--within the limits of socially constructed reality. Decisions and actions are often spontaneous, but we interpret them with customary frameworks. People's accounts of a single action, then, may vary, but their accounts conform to one or another of the collective interpretive frameworks currently in use. Because people's cognitive frameworks are shaped by experience with social customs, each of us is equipped with a range of frameworks for interpreting behavior.

\subsubsection{The Institutionalization of Rational Myths}

John Meyer and Brian Rowan's 'Institutionalized Organizations: Formal Structure as Myth and Ceremony' (1977) shook up the world of organizational sociology by proposing a constructionist approach to understanding organizational practices and routines. Meyer and Rowan describe modern organizations as adopting structures that symbolize rationality and fairness, and describe those structures as 'myth and ceremony'. At the time, the prevailing view of the farm was that economic laws determined 'best practices' and that those 'best practices' would come to the surface everywhere. If organizations looked alike, it was because they were subjected to the same economic pressures. If they had accounting departments and strategic planning teams and performance evaluations, it was because each organization had found each one of those practices to be efficient.

Meyer and Rowan's revolutionary article described rationalized organizational practices as symbolic and ritualized, even though those practices often symbolize rationality. Organizations adopt practices that embody myths of rationality both to trumpet their commitment to efficiency and to achieve it. Not only within organizations (as March and Simon point out) but also across organizations, we socially construct reality by classifying behavior patterns, norms, and rules and linking them to myths of rationality. Meaningful 'institutions' thus shape behavior in organizations: 'Institutionalized rules are classifications built into society as reciprocated typifications or interpretations' (Meyer and Rowan 1977: 341).

It is not tribal elders who invent new organizational rituals, for institutionalists, but entrepreneurs who devise new rituals and promote them directly as rational problem-solving devices to members of their networks, and to the wider management audience through cover stories in Fortune or Harvard Business Review. New practices - quality circles, empowerment, high-performance work practicesbecame 'institutionalized' (taken for granted) as this process proceeds. Those practices must conform to the wider understanding of what is rational, and so it is easier to sell certain kinds of practices in Marseilles than in Minneapolis. In Meyer and Rowan's world, frrms come to look alike becatse they jump on the same 
bandwagons and not, pace functionalist organizational theorists, because each figares out the single best way to organize.

In 1983, Paul DiMaggio and Walter Powell built on this idea, sketching the networks through which new rational customs diffuse among organizations-political networks, professional networks, and networks of firms. Schools were coming to look more like one another, and so were hospitals, auto factories, and charities. A growing body of standard practices could be found in each field. Like Meyer and Rowan, DiMaggio and Powell described the driving force behind institutionalization as social. Auto plants do not resemble one another because their managers independently invent the same business practices, but because they copy from the same sources.

Each new practice comes fully equipped with a story about why it is efficient, just as, in Durkheim's tribes, each ritual comes with a story about why the spirit world requires it. The spread of rituals across organizations usually follows one of three patterns. Sometimes public policy encourages organizations to adopt new conventions ('coercive isomorphism'). For instance, federal regulations dictate that schools must meet certain standards or give certain tests (Meyer and Scott 1983). Sometimes professional networks that span organizations promote new conventions with native, usually untested, theories of their efficacy ('normative isomorphism'). For instance, finance managers promoted the portfolio approach to corporate diversification (Fligstein 1990). Sometimes managers copy practices of successful organizations without a clear theory of how the new innovation works ('mimetic isomorphism'). For instance, American automakers copied Japanese production strategies willy-nilly after Japan made inroads into America's auto market. Mimetic isomorphism can have the character of a cargo cult, in which the tribe builds a wooden replica of a cargo plane in the hope that the replica will bear the same fruit as the real plane.

Key business strategies often spread through mimetic isomorphism, and as Heather Haveman (1993) shows in a paper titled 'Follow the Leader', firms that are defined as industry leaders due to high growth or sheer size are more likely than others to be copied by their peers. Among savings and loans, when industry leaders diversify into real estate or into commercial loans, other firms follow their lead. The very definition of a savings and loan is changed in the process.

Diffusion of management myths made sectors quite internally homogeneous in the post-war period, and diffusion across sectors has in recent decades made organizational practices homogeneous across sectors (Meyer 1994). With the rise of a generic, non-sectoral, model of organizing, social service agencies increasingly appoint $\mathrm{CEO}$ and hospitals increasingly write mission statements-innovations that first appeared in the for-profit world.

Meyer and Rowan and DiMaggio and Powell describe how myth and ceremony contribute to the spread of rational conventions through the forest of organizations. The quality management movement, for example, turned the tide against the earlier 
movements of Taylorism and Fordism to encourage production workers to help design the production process (Cole 1989). The movement spread the idea that worker participation in job design could be more efficient than a strict division of labor between those who design assembly lines and those who work on them. To calt the new theory of empowerment a rational myth is not to say that there is nothing to it. It is to suggest that such ideas are the myth, and that related practices are the ceremony, around which rationalized organizational cultures are constructed.

\subsection{Second-Wave Power Theorists and Cognitive Classification}

Mid-twentieth-century American theories of power, exemplified by C. Wright Mills (1956), focused on the elite and their capacity to control corporations and institutions. Since the rise of institutional theory, students of capitalist firms have imported social constructionist insights to build a constructionist theory of power. Neil Fligstein's The Transformation of Corporate Control (1990) brings insights from the social constructionist paradigm that Durkheim inspired to the study of strategy among America's largest corporations.

Fligstein's work on corporate management is framed as the antithesis of The Visible Hand (1977), by America's pre-eminent business historian, Alfred DuPont Chandler, who told the story of the evolution of corporate control from the perspective of business efficiency. Early firms were run by managers with backgrounds in production. Later, sales and marketing managers took over, as the axis of firm competition shifted from production to marketing. Later still, finance managers took over, as firms shifted focus from sales and marketing to diversification. Chandler treats these changes as part of the natural progression of the modern firm, from a perspective that was more evolutionary than sociological.

Fligstein finds that these changes were the result of a series of power struggles among management factions. Each group succeeded in taking control of the large corporation by convincing investors that its management speciaity held the key to corporate efficacy. Under each equilibrium, people came to understand the worid in terms of the business customs and institutions they faced. These equilibriums constitute social constructions of reality, or 'conceptions of control' in Fligstein's terms. Each equilibrium was disrupted by an external shift that required business leaders to search for a new model of behavior, and a new theory of the firm or 'conception of control.'

The shift from sales to finance management was kicked off in 1950 when Congress passed the Celer-Kefauver Act, which made it difficult for firms to acquire others 
in related businesses. Finance managers responded with a new business model, later reinforced by portfolio theory in financial economics, in which the large firm should not act like a marketing machine growing in a single sector, but like an investor with a diversified portfolio. Finance managers now argued before corporate boards and investors that the diversified conglomerate was the way of the future and that they, finance managers, were best qualified to manage conglomerates. They thereby came to displace experts in sales at the helms of the biggest corporations.

Under Fligstein's political-cultural approach, business customs and institutions are held in place by beliefs. Belief in the rationality of existing customs and institutions comes from experience with them (as does belief in the totem in Durkheim's Australian tribes), and from rational theorization by consultants, economists, and management theorists (the equivalent of witch-doctors and tribal elders). When an external shock-a recession, a policy shift-destabilizes one broad business strategy, entrepreneurial consultants and managers promote new practices and theories to go along with them. The powerful are most likely to be able to put their preferred alternatives into place. Once in place, the new business strategy is held in place by a theory that makes sense within the existing social construction of reality. The conglomerate model of the firm, then, was shaken by policy and economic shifts circa 1980, and institutional entrepreneurs successfully promoted a new model rooted in ideas about 'core competence' in management (Davis, Diekmann, and Tinsley 1994; Fligstein and Markowitz 1993). In Durkheim's terms, the collective consciousness changes when the social rituals of the corporation change.

Fligstein's second-wave power theory, then, builds directly on the insights that Meyer and Rowan developed in their institutional approach to explain how culture and legitimacy reinforce particular organizational strategies, across the organizational field. One of Fligstein's innovations is to explore how power shapes what emergent strategies will look like. Like Durkheim, Fligstein emphasizes that the collective constructions of rituals is what keeps them in place and emphasizes that this construction is a social rather than an individual process.

William Roy, in Socializing Capital: The Rise of the Large Industrial Corporation in America (1997), sketches a somewhat different theory of the role of power under modern capitalism, but one which also owes a debt to Durkheim and the social constructionists. Under his theory, the social construction of efficiency keeps particular policy regimes, and corporate strategies, in place. Public and organizational policies that are put in place because they support the interests of particular groups become legitimated through rhetorical strategies and economic theories, and institutional power differentials thus become obscured. The power of groups that put new policies in place is thus sustained through the cultural legitimacy gained by those policies.

Roy seeks to explain a wave of mergers at the beginning of the twentieth century that produced huge industrial enterprises and a business model based on economies of scale. For Roy, the initial enforcement of antitrust in 1897 had an unanticipated 
effect on the balance of power between large and small firms. It was not only economies of scale that gave big firms an edge and spawned a merger wave, as Alfred Chandler (1977) contends, because firms merged even in industries that coutd not benefit from economies of scale. Roy argues that, when antitrust prevented firms from joining together to set prices, large firms demanded that smaller competitors sell out or face certain death in price wars. The huge concentrated firm was born of an unanticipated coincidence of public policy and private power. Public policy fostered price competition, and large firms forced their smaller competitors to sell out.

One result is that the theory of economies of scale received a boost, and Americans came to see the large corporation as inevitable because of its superior efficiency. Public policy was increasingly tolerant of large firms, and growth in size was seen less as an effort to extinguish competition (as it had been seen circa 1890) and more as a move towards efficiency. Americans soon came to take the huge industrial enterprise for granted, and to presume that large firms are large because they enjoy economies of scale. For Roy, once this pattern was established, it became self-reinforcing, largely because people make sense of the world around them by attributing rationality to practices, explaining surviving economic solutions teleologically, as a consequence of evolution and natural selection. This collective process of making sense of rituals, and giving social practices meaning in the process, closely parallek Durkheim's discussion of tribal religions.

For Roy, the successful theorization of new organizational practices means that they no longer have to be actively supported by the powerful. They become taken for granted, and advantages to certain groups (in the United States, owners of large corporations) become institutionalized.

This pattern of making sense of the social customs of the world collectively, and doing so iteratively and interactively, is very much what Durkheim described in his study of primitive classifications, and in Elementary Forms. For Roy and Fligstein alike, organizational rituals are given meaning through collective social construction, as for Durkheim, and then they are held in place by that meaning. They become ritualized as they are connected to a totem, or an economic or social law, that rules society from without.

\subsection{Conclusion}

In totemic societies, Durkheim found the same broad form of meaning-making that he had seen in modern religious societies. In both settings, people categorized things to make sense of the world. In both, they traced physical and social patterns 
to forces outside of society - to a spirit world or to a religious wortd with a single deity. For Durkheim, it is human nature to make sense of the world collectively and to assign to things in the world meaning, most simply as sacred or profane. For Durkheim, social processes produce our mental categories-our ideas-and those mental categories have real effects in the world (Rawis 1996; Emirbayer 1996).

I began by arguing that Durkheim's influence on the organizational sociologists who have championed a cultural approach has largely been neglected. Durkheim was the first to recognize the mechanisms by which totemic tribes make sense of the world. They categorized the objects and customs and beings in the world around them, drawing connections between things as a way of making collective sense of them. Modern religious systems, and rationalized systems, made sense of the world in much the same way. That may be the key insight underlying social constructionist approaches to the modern organization, namely, that the human inclination to try to make sense of the world as it is given to us leads us to develop shared mental maps of the world, categorizing things and people and theories and then projecting those categorizations onto a force that is exogenous to society itself.

Those mental maps of the world, which Durkheirn described as collective consciousness, are what keep modern organizational practices in place. It is because we attach meaning to the chain of command, the job ladder, or the disciplinary procedure that we sustain those organizational practices, day in and day out. It is because we share a broad, socially produced, system of meaning that we understand the logic of organizational innovations, recognizing that they operate under a theory of professional expertise, or of empowerment, or of the division of labor itself.

In the last generation, organizational sociology has undergone a revolution. The classic studies in the field had been designed to divine the universal social laws that governed efficiency in social organization. 'Frederick Taylor's (1911) Scientific Management purported to identify the optimal work patterns on the shop floor, and later the assembly line, and the optimal division of labor between workers and managers. More than half a century later, Peter Blau (1970) and Joan Woodward ([1958] 1984) were still seeking to understand the universal social laws that determined the optimal span of supervisory control in the factory, or the optimal number of layers of bureaucracy. In the meantime, March and Simon (1958), Roethlisberger and Dickson ([1939] 1981), Selznick (1957), and Zald and Denton (1963) had sought to understand the irrational, human side of organizational behavior. But their studies had not challenged the central view of organizational sociologists, that organizational practices were driven by universal laws of efficiency. Instead, they challenged the view that real people in real organizations can operate according to precepts of rationality.

The hyper-rationalist studies depended on a view of the organization that came from within the scientific-rational worldview. Under that view, the modern scientific-rational world is fundamentally different from the spiritual and religious 
worlds that preceded it because it is not based on myth and ceremony, but on an accurate comprehension of the nature of reality. In place of superstition and hocus pocus, we now have a scientific approach to understanding the world around us that will eventually yield truth, even if there are some misstcps along the way. Observable organizational practices in this system reflect universal laws of efficiency, or they will eventually come to reflect those laws, even if there are some false starts in the process and even if such cognitive constraints as bounded rationality get in the way.

While they were developed in the context of totemic systems, Durkheim's observations about the collective creation of meaning provide a lens for viewing religious and scientific-rational social systems as collectivcly constructed. Since the late 1970s, organizational scholars have stepped back from the rationalized practices of the modern firm, asking how we came to believe those practices to be rational rather than what the transcendental laws of rationality underlying those laws are. One reason for this revolution was growing awareness of organizational systems outside of the United States that operated differently. Those systems-in countries such as Japan, France, and Germany--made organizational scholars realize that if laws of organizational efficiency existed, they seemed to be local rather than transcendental. And so organizational scholars began to do just what Durkheim did. Durkheim had compared tribal societies to understand the mechanisms by which they collectively construct spiritual systems, and organizational scholars began to compare national organizational systems to understand the mechanisms by which they collectively construct rational systems (and laws of organizational efficiency) (Hofstede 1980; Whitley 1992).

Most of the social constructionist organizational studies that build on Durkheim's insights have taken a single country as their focus and have charted change over time in the social construction of organizational efficiency (Fligstein 1990; Roy 1997). This project has now pinned down a number of insights concerning how new organizational paradigms diffuse through social networks, how institutional entrepreneurs convince others of the efficacy of the programs they promote, and how power relations come into play in the rise of new conceptions of how to organize firms. But the project is new, and there is much work to do to further pin down how these mechanisms work. That work is typically broad in scope, involving hundrcds of organizations observed over time, and sometimes across continents.

As most of the constructionist work to date has focused on organizational fields, there are three important areas of research at different levels of analysis that require further research. First, we understand poorly the mechanisms by which organizational innovations diffuse across nations and are changed in the process of diffusion (but see Guillén 1994; Djelic 1998; Czarniawska-Joerges and Sevon 1996). How are new social constructions of efficiency put into place in countries that have no experience with them or with the building blocks from which they arc assembled? Second, what goes on within the firm is largely a black box, for most studies focus on the diffusion of new rituals without asking how they are implemented in 
individual firms. We little understand the organizational mechanisms by which new innovations are brought into the firm, put into place, and made sense of locally (but see Lounsbury and Glynn 2001; Pedersen and Dobbin 2006). Third, we understand poorly how new organizational rituals and native theories of organizing emerge through interaction, perhaps in what Randall Collins (2004), following Durkheim and Goffman, dubs 'interaction ritual chains'. How do organizational innovations first bubble up through interaction rituals? These are all questions that would have been at the top of Durkheim's own to -do list.

\section{ACKNOWLEDGMENTS}

Thanks to Paul Adler, Michael Cohen, Anne Fleischer, Mark Kennedy, and Steve Mezias for comments and Lynn Childress for expert editing.

\section{REFERENCES}

Barley, S. R., and KundA, G. (1992). 'Design and Devotion: Surges of Rational and Normative Ideologies of Control in Managerial Discourse'. Adrinistrative Science Quarterly, 37: $363-400$.

Berger, P. L. (1967). The Sacred Canopy. Garden City, NY: Doubleday.

-and Luckmann, T. (1966). The Social Construction of Reality: A Treatise in the Sociology of Knowledge. Garden City, NY: Doubleday.

Bergesen, A. J. (2004). 'Durkheim's Theory of Mental Categories: A Review of the Evidence'. Antual Review of Sociology, 30: 395-408.

Buav, P. M. (1970). 'A Formal Theory of Differentiation in Organizations'. Arrerican Sociological Review, 35: 201-18.

Boltanski, L., and Thevenot, L. (1991). De la justification: Les Economies de la grandeur. Paris: Gallimard.

Chandler, A. D., Jr. (1977). The Visible Hand: The Managerial Revolution in American Business. Cambridge, Mass.: Belknap.

COLE, R. E. (1989). Strategies for Learning: Small-Group Activities in American, Japanese, and Swedish Industry. Berkeley: University of California Press.

Collin, F. (1997). Social Reality. London: Routledge.

ColuIns, R (2004). Interaction Ritual Chains. Princeton: Princeton University Press.

Czarniawska-Joerges, B., and Sevon, G. (eds.) (1996). Translating Otganizational Change. Berlin: de Gruyter.

Davis, G. F., Diekmann, K. A., and Tinsley, C. H. (1994). 'The Decline and Fall of the Conglomerate Firm in the 1980s: The Deinstitutionalization of an Organizational Form'. American Sociological Review, 59:547-70. 
DEWEY, J. (ed.) (1998). The Essential Dewey, vols. I and 2. Bloomington: Indiana University Press.

DiMaggio, P. J. (1997). 'Culture and Cognition'. Annual Review of Sociology, 23: 263-87.

- and Powell, W. W. (1983). 'The Iron Cage Revisited-Institutional Isomorphism and Collective Rationality in Organizational Fields'. American Sociological Review, 48: $147-60$.

Djelic, M.-L. (1998). Exporting the American Model: The Postwar Transformation of European Business. New York: Oxford University Press.

Dobrin, F. (2004). 'The Sociological View of the Economy', in F. Dobbin (ed.), The New Economic Sociology: A Reader. Princeton: Princeton University Press.

DORE, R. (2000). Stock Market Capitalism: Welfare Capitalism-Japan and Germany Versus the Anglo-Saxons. New York: Oxford University Press.

Douglas, M. (1966). Purity and Danger: An Analysis of Concepts of Pollution and Taboo. London: Routledge.

- (1986). How Institutions Think. Syracuse, NY: Syracuse University Press.

DuRKHEIM, E. ([1893] 1933). The Division of Labor in Society. New York: Free Press.

- $([1895]$ 1966). The Rules of Sociological Method. Glencoe, Ill.: Free Press.

_- ([1897] 1966). Suicide: A Study in Sociology. New York: Free Press.

$-([1897] 1966)$. Suicide: A Study in Sociology. New York: Free Press.
- ([1912] 1961). The Elementary Forms of the Religious Life. New York: Collier.
- and Mauss, M. ([1902] 1963). Primitive Classification. London: Cohen and West.

EMIRBAYER, M. (1996). 'Useful Durkheim'. Sociological Theory, 14: 109-30.

Fligstein, N. (1990). The Transformation of Corporate Control. Cambridge, Mass.: Harvard University Press.

and MaRKowitz, L. (1993). "Financial Reorganization of American Corporations in the 1980s', in W. J. Wilson (ed.), Sociology and the Public Agenda. Beverly Hills: Sage Publications.

GeERTZ, C. (1983). Local Knowledge: Further Essays in Interpretive Anthropology. New York: Basic.

Goffman, E. ([1967] 2005). Interaction Ritual: Essays in Face to Face Behavior. New Brunswick, NI: Aldine Transaction.

- (1974). Frame Analysis. Cambridge, Mass.: Harvard University Press.

GREIF, A. (1993). 'Contract Enforceability and Economic Institutions in Early Trade: The Maghribi Traders' Coalition'. American Economic Review, 83: 525-48.

GuILIÉN, M. F. (1994). Models of Management: Work Authority and Organization in a Comparative Perspective. Chicago: University of Chicago Press.

HaVmman, H. A. (1993). 'Follow the Leader: Mimetic Isomorphism and Entry into New Markets'. Administrative Science Quarterly, 38: 593-627.

Hirschman, A. O. (1977). The Passions and the Interests: Political Arguments for Capitalism before its Triumph. Princeton: Princeton University Press.

HobBes, T. (1982). Leviathan. London: Penguin.

HofsTEDE, G. (1980). Culture's Consequences: International Differences in Work Values. Beverly Hills, Calif.: Sage.

JoAs, H. (1993). Pragmatism and Social Theory. Chicago: University of Chicago Press.

LÉvi-STrauss, C. (1978). Myth and Meaning. London: Routledge and Kegan Paul.

LINCOEN, ,., and Gulloor, D. (2005). A Durkheimian View of Organizational Culture. Oxford: Oxford University Press.

Locke, J. (1965). Two Treatises of Government. New York: Mentor. 
Lounseury, M., and GLYNN, M. A. (2001). 'Cultural Entrepreneurship: Stories, Legitimacy and the Acquisition of Resources'. Strategic Management Journal, 22: 545-64.

LuKES, S. (1985). Emile Durkheim: His Life and Work, a Historical and Critical Study. Stanford, Calif.: Stanford University Press.

March, J. G., and Srmon, H. A. (1958). Organizations. New York: Wiley.

Martin, J. (2002). The Education of John Dewey: A Biography. New York: Columbia University Press.

MARX, K. ([1852] 1963). The Eighteenth Brumaire of Louis Bonaparte. New York: International.

- $\{[1859]$ 1968). Preface to a Contribution to the Critique of Political Economy, in K. Marx and F. Engels (eds.), Selected Works. London: Lawrence \& Wishart.

MeYer, J. W. (1994). 'Rationalized Environments', in W. R. Scott and J. W. Meyer (eds.), Institutional Environments and Organizations: Structural Complexity and Individualism. Thousand Oaks, Calif.: Sage.

- and Rowan, B. (1977). 'Institutionalized Organizations: FormaI Structure as Myth and Ceremony'. American Journal of Sociology, 83: 340-63.

- and ScotT, W. R. (1983). Organizational Environments: Ritual and Rationality. Beverly Hills, Calif.: Sage.

Mrlis, C. W. (1956). The Power Elite. New York: Oxford University Press.

Nisbett, R. E., Peng, K., Choi, I., and Norenzayan, A. (2001). "Culture and Systems of Thought: Holistic Versus Analytic Cognition'. Psychological Review, 108: 291-310.

PeDERSEN, J. S., and DobBiN, F. (2006). 'In Search of Identity and Legitimation: Organizational Culture and Neoinstitutionalism'. American Behavioral Scientist, 49: 897-907.

Rawls, A. W. (1996). 'Durkheim's Epistemology: The Neglected Argument'. American Journal of Sociology, 102: 430-82.

ROETHLISBERGER, F. J., and DiCKsON, W. J. ([1939] 198I). 'Human Relations', in O. Grusky and G. A. Miller (eds.), The Sociology of Organizations: Basic Studies, and edn. New York: Free Press.

RoY, W. (1997). Socializing Capital: The Rise of the Large Industrial Corporation in America. Princeton: Princeton University Press.

SCHEIN, E. H. (1996). 'Culture: The Missing Concept in Organization Studies'. Administrative Science Quarterly, 41: 229-40.

Schutz, A. ([1932] 1967). The Phenomenology of the Social World. Evanston, III.: Northwestern University Press.

SELZNICK, P. (1957). Leadership in Administration: A Sociological Interpretation. New York: Harper and Row.

SMELSER, N. J. (1995). 'Economic Rationality as a Religious System', in R. Wuthnow (ed.), Rethinking Materialism: Perspectives on the Spiritual Dimension of Economic Behavior. Grand Rapids, Mich.: William B. Eerdmans.

Somers, M. M. (2001). 'Romancing the Market, Reviling the State: Historicizing Liberalism, Privatization, and the Competing Claims to Civil Society', in C. Crouch, K. Eder, and D. Tambini (eds.), Citizenship, Markets, and the State. New York: Oxford University Press.

Swedrerg, R. (2003). Principles of Economic Sociology. Princeton: Princeton University Press.

SwIDLER, A. (1986). 'Culture in Action: Symbols and Strategies'. American Sociological Review, 51: 273-86.

TAYLOR, F. W. (2911). Scientific Management. New York: Harper. 
TURNeR, B. S. (1997). The Absent Body in Structuration Theory. London: Routledge. WEBER, M. (1978). Economy and Society. Berkeley: University of California Press.

WEICK, K. E. (1995). Sensemaking in Organizations. Thousand Oaks, Calif: Sage.

Whitrey, R. (1992). Business Systems in East Asia: Firms, Markets, and Societies. London: Sage.

and Kristensen, P. H. (eds.) (1996). The Changing European Firm: Limits to Convergence. London: Routledge.

WOOdWARd, ]. ([1958] 1984). 'Management and Technology', in D. S. Pugh (ed.), Organization Theory: Selected Readings, and edn. New York: Penguin.

ZALD, M. N., and Denton, P. (1963). 'From Evangelism to General Service: The Transformation of the YMCA'. Administrative Science Quarterly, 8: 224-34. 